\title{
SUSPENDED SHELLFISH CULTURE IMPACTS ON THE BENTHIC LAYER: A CASE STUDY IN BRAZILIAN SUBTROPICAL WATERS
}

\author{
Natália de Moraes Rudorff*, Carla Van Der Haagen Custodio Bonetti and Jarbas Bonetti Filho \\ Universidade Federal de Santa Catarina \\ Departamento de Geociências, Laboratório de Oceanografia Costeria \\ (Rua Beco dos Coroas, Barra da Lagoa, 88040-900, Florianópolis, SC, Brasil) \\ * Corresponding author: nmr@dsr.inpe.br
}

\section{A B S T R A C T}

This study aimed to assess benthic impacts of suspended shellfish cultures in two marine farms located in South Bay, Florianópolis (SC, Brazil). The goal was to detect changes in the benthic layer and evaluate the influence of local conditions, such as hydrodynamics and geomorphology, on the degree of impact at each site. The method included analysis of three groups of oceanographic descriptors: hydrodynamic; morpho-sedimentological (bathymetry, grain size and organic content), and ecological (foraminiferal fauna). Data sets were analyzed using geostatistical and multivariate techniques. Ecological descriptors seemed to be more effective under different environmental conditions than sedimentological variables. Those that best identified culture-related biodeposits, were: dominance of Ammonia tepida; test size; and living: total population ratio. Only slight differences were observed within and outside the culture structures. However, a greater alteration was observed at the site with weaker hydrodynamics and located in shallower depths. The conclusion is that biodeposition at studied still causes little alteration in the local benthic environment. However, local factors such as hydrodynamics and geomorphology were shown to be important in minimizing these impacts. These are criteria that should be considered in site selection programs for the development of this productive activity.

\section{R E S U M O}

O presente trabalho investigou os impactos de cultivos suspensos de moluscos sobre a camada bêntica em duas fazendas marinhas na Baía Sul, Florianópolis (SC, Brasil). O objetivo foi detectar mudanças no ambiente de fundo e avaliar a influência de condições locais, como a hidrodinâmica e geomorfologia, no grau de impacto em cada sítio. O método empregado compreendeu análises de três grupos de descritores oceanográficos: hidrodinâmicos, morfossedimentológicos (batimetria, granulometria e constituintes orgânicos) e ecológicos (fauna foraminífera). Os dados foram analisados com técnicas geoestatísticas e multivariadas. Os descritores ecológicos aparentemente foram mais representativos sob diferentes matrizes ambientais que os sedimentológicos. Os que melhor identificaram áreas sob influência dos cultivos foram: dominância de Ammonia tepida, tamanho das testas e razão foraminíferos vivos: totais. Somente pequenas diferenças foram encontradas dentro e fora das áreas de cultivo. Não obstante, maiores graus de alteração foram observados no sítio com menor hidrodinâmica e profundidades mais rasas. Concluiu-se que o aporte dos cultivos nos sítios estudados ainda ocasiona poucas alterações no ambiente bentônico. No entanto, os fatores locais de hidrodinâmica e geomorfologia foram importantes na minimização dos impactos. Estes devem ser considerados com critérios em programas de seleção de áreas propícias para o desenvolvimento da atividade.

Descriptors: Shellfish Culture, Impacts on Benthic Layer, Foraminifera, South Bay, Florianópolis, Brazil.

Descritores: Cultivo de Moluscos, Impactos na Camada Bêntica, Foraminifera, Baía Sul, Florianópolis, Brasil. 


\section{INTRODUCTION}

With the decline of fishery stocks, aquaculture has become a promising activity to meet consumers' demands, avoiding the greater pressures of natural exploitation (FAO, 2010). The activity has indeed many social, economic and environmental benefits. However, as any other human activity it also has potential impacts which must be carefully analyzed and monitored. Shellfish culture has been indicated as one of the productive systems that cause the least impact on the environment, in some cases showing no or only minor alterations compared to other potential tensors in coastal areas (GRANT et al., 1995; BONETTI et al., 2006a). However, there are potential impacts of shellfish culture, and in many cases, eutrophication of the benthic layer has also been reported (MATTSON; LINDÉN, 1983; OTERO et al., 2006). Mussels are filtering feeders that release digested excretes in the form of feces and pseudofeces. These excretes are aggregates of organic and inorganic compounds that are deposited on the seabed beneath the culture structures (DAME, 1996). The organic flux can initially be beneficial to the environment due to the resulting increase of available nutrients. However, if it exceeds the limits of benthic assimilation, a biodeposit layer can accumulate on the seabed, causing a negative impact on the benthic layer that can even affect the water column, provoking a reduction in natural and shellfish production (BARG, 1992). The main alterations caused by the presence of biodeposits are: increases in muddy sediments of a gray or blackish color, higher levels of organic compounds, and the accumulation of broken mussel shells. Diminished benthic community biodiversity due to increased abundance of opportunistic species has also been observed (MATTSON; LINDÉN 1983; KASPAR et al., 1984; CHAMBERLAIN et al., 2001).

Many models have been proposed for the prediction of the environmental impacts of marine aquaculture, but most of them focus on finfish systems (CROMEY et al., 2002; JUSUP et al., 2007) that have levels of interaction different from those of shellfish cultures (MCKINDSEY et al., 2006). The feces and pseudofeces released by mussels and oysters are highly porous (GRENZ et al., 1990) and may undergo various processes of physical-chemical and biological alteration before accumulating on the seabed (HARTSTEIN; RODWEN, 2004). The complexity of these interactions, especially in nearshore coastal systems, implies a highly diverse range of conditions which interfere with the environmental responses and cause different degrees of impact. It is basically for this reason that few studies have recorded any - or only minor - impacts resulting from mussel culture (SCOTT et al., 1995; GRANT et al., 1995; CRANDFORD et al., 2003; MALLET et al., 2006) while others have shown moderate (BOUCHET; SAURIAU, 2008) or even major impacts (MATTSON; LINDÉN, 1983; KASPAR et al., 1984). According to Chamberlain and collaborators (2001), the main determining factors of the degree of impact are the conditions under which the culture is undertaken, such as species cultivated, density and structure employed, and the local conditions (mainly depths and hydrodynamics). These factors are clearly known to influence the benthic environment (HARTSTEIN; RODWEN, 2004; BOUCHET; SAURIAU, 2008; LONGDILL et al., 2008). However, the main processes involved, the critical levels and the environmental consequences, including an evaluation of the area indirectly affected by the geographical extent of the culture, are still undergoing investigation (HARTSTEIN; STEVENS, 2005; MCKINDSEY et al., 2006). Furthermore, most available research on the benthic impact of shellfish cultures concerns temperate regions which may present interactions and responses distinct from those found in tropical and sub-tropical zones (BARG, 1992).

Benthic bioindicators have been used in many environmental research studies to evaluate and identify impacts on marine and coastal systems. Foraminifers have been used in many of these studies, including those on aquaculture impacts (SCOTT et al. 1995; ANGEL et al. 2000; BOUCHET et al. 2006; BONETTI et al., 2006b). These organisms are testate protozoans found in all marine environments (NICHOLS, 1974), and have become extremely useful in environmental and paleoenvironmental reconstructions due to their ability to respond quickly to oceanographic changes and to conserve their tests throughout geological time. In addition to the advantages of their use, these microorganisms are small and very abundant in the sediment, facilitating their retrieval in small samples. They are, therefore, useful for statistical analyses, offering a cost-effective tool for impact assessment (MURRAY, 1991; SCOTT et al. 1995).

In this context, the present study aimed to assess benthic impacts of shellfish cultures at two sites located in South Bay, Florianópolis (SC/Brazil). The main goal was to evaluate the impacts and how local conditions, such as hydrodynamics and depths, can contribute to their reduction. A set of relatively simplified and low cost biosedimentological descriptors, such as grain size, organic content and foraminiferal fauna, were applied for this purpose.

\section{Material and Methods}

The area chosen for this study lies in a coastal system named South Bay (Baía Sul), located between the parallels $27^{\circ} 20^{\prime} \mathrm{S}$ and $27^{\circ} 50^{\prime} \mathrm{S}$, on the 
southeastern coast of Brazil. This system accounts for most of Santa Catarina State's shellfish production, responsible for $95 \%$ of the national supply. In 2009, the state produced 10,891 tons of mussels and 2,213 tons of oysters. This activity was begun in the early 80 's and grew rapidly, still having great potential for expansion into new areas (EPAGRI, 2009).

South Bay is a sheltered formation that separates the mainland from the Island of Santa Catarina. It has an area of approximately $125 \mathrm{~km}^{2}$ and two outlets, one of which is located at its southern tip and connects it to the Atlantic Ocean, the other being in the north and connecting it to a similar system called North Bay (Baía Norte) (Fig. 1). The region is subject to the influence of micro tides $(<2 \mathrm{~m})$ and fluxes enter the system through both outlets. Due to the local geomorphology, the two converging branches of the tidal flow meet in the northern sector of South Bay and create a very low local hydrodynamic regime ( MELO et. al., 1997). Thus, the northern sector is dominated by weak hydrodynamic conditions, whereas the southern sector is exposed to stronger tidal currents due to the presence of deep circulation channels and its proximity to the ocean. Beyond the astronomical tides, this region is also influenced by the meteorological tides associated with periodic storm surge events related to the passage of cold fronts. These meteorological systems promote strong persistent southerly winds that intensify the surface currents and local waves inside the bay (MELO - et al., 1997).
The specific sampling sites selected for this study were located in the central-northern part of South Bay. One of the areas is located within a sheltered bight, close to a mangrove system and subject to weak hydrodynamics; the other, located further south, faces more intense conditions due to its exposure to currents and winds. The site in the north was named Alto Ribeirão and that in the south Museu Beach (Fig. 1). At both sites the farms use "long-line" culture systems - structures consisting of iron lines floating on the surface, attached to airfilled buoys anchored to concrete blocks on the seafloor. The buoys support the ropes and net structures of mussels and oysters suspended in the water column. The lines (called "long-lines" by shellfish producers) are about $100 \mathrm{~m}$ long, arranged in parallel (in accordance with the direction of the local currents). Both farms grow the exotic oyster Crassostrea gigas and the native mussel Perna perna, placed in alternate order along the long-lines. The density used for oyster cultivation is around 360 oysters per cage ("lantern"), at depths from 2 to 4 meters, after 10 to 12 months of cultivation. The Perna perna mussel achieves a final production of 700 to 800 mussels per rope after 7 to 9 months of cultivation (FERREIRA; MAGALHÃES, 2004). The Alto Ribeirão farm has 18 long-lines in an area of 100 $\mathrm{x} 150 \mathrm{~m}^{2}$ with seven years of production in the oldest sector. The Museu Beach farm has 18 long-lines in an area of $100 \times 200 \mathrm{~m}^{2}$, with ten years of production.

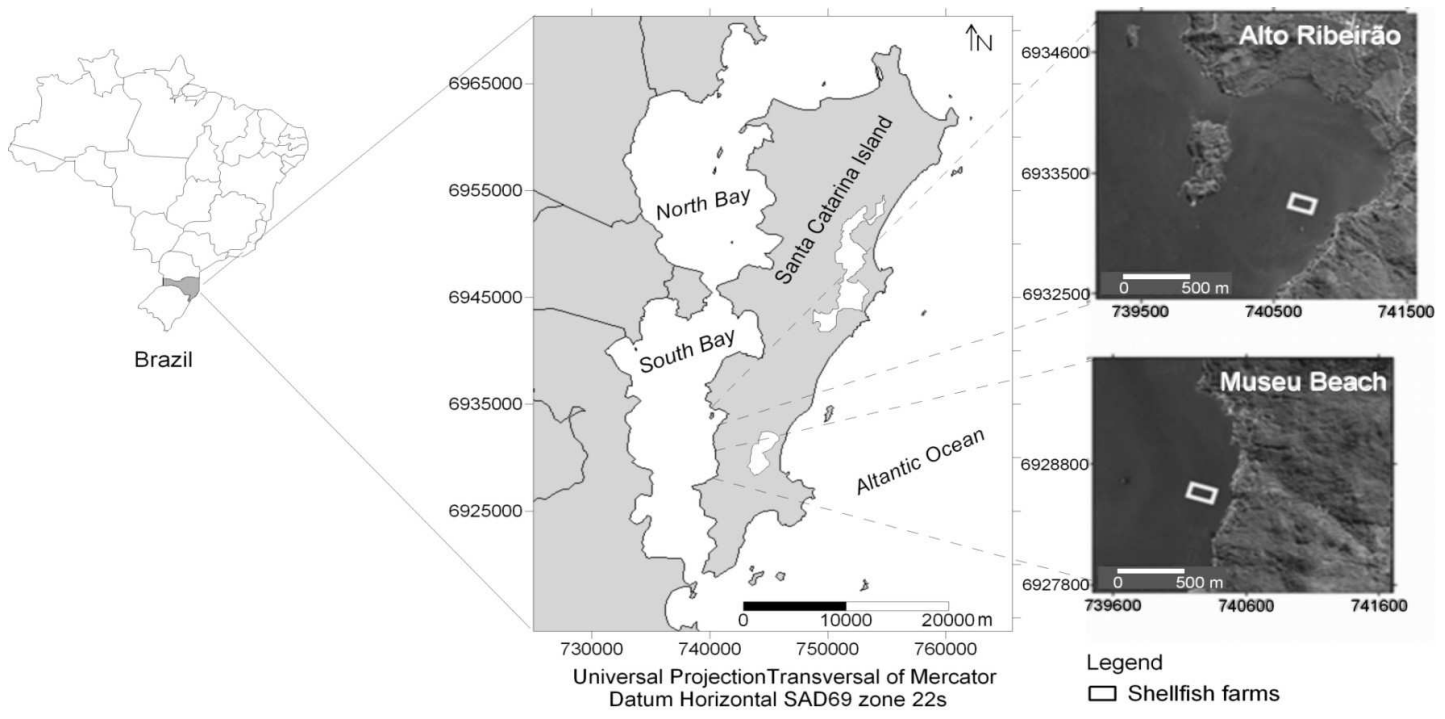

Fig. 1. Localization of Alto Ribeirão and Museu Beach sites. (Approach map with QuickBird images of 2007, obtained from Google Earth server). 
Hydrodynamics and Physical-Chemical Variables

The hydrodynamic survey involved the continuous registration of current intensity and direction during a 13-hour tidal cycle. In order to measure the greatest amplitudes of the fluxes, the field measurements were undertaken during the spring tides combined with the passage of a cold front and persistent, strong southerly winds. The meteorological conditions were monitored by weather forecast and images from geo-stationary satellites. The field campaign took place on two consecutive days, November $25^{\text {th }}$ and $26^{\text {th }}, 2007$ at both sites. Currents were measured by a Sontek Acoustic Doppler Current Profiler (ADCP) programmed to register mean currents (velocity and direction) every 10 minutes at depth intervals of 17 and $30 \mathrm{~cm}$ along the water column (for sites 1 and 2 , respectively). The equipment was moored at the center of each farm, where the fluxes are most affected by the culture structures. A multi-probe system (YSI 556 MPS) was used to measure salinity and dissolved oxygen in surface and bottom waters. Turbidity was also measured in NTU units with a portable turbidimeter. Wind data were acquired from the Meteorological Station of the Airport of Florianópolis, near the study area.

\section{Bathymetry}

The bathymetric survey covered the farms and their surrounding areas with equidistant points 20 $\mathrm{m}$ apart. The survey accompanied the alignment of the long-lines within the culture areas and two external radial profiles 30 and 75 meters from the farm boundary. Depth measurements were obtained by a Hondex portable echosounder associated with a Differential Global Positioning System (DGPS). A graduated $5 \mathrm{~m}$ telescopic leveling staff was also used at lesser depths to improve the accuracy of the measurements. The field work was undertaken on March $13^{\text {th }}, 2007$ at the Museu Beach site and on May $7^{\text {th }}, 2007$ at the Alto Ribeirão site.

\section{Biosedimentological Parameters} Sampling Design

The sample stations were located in accordance with the local morphological gradient (Fig. 2 ), previously established by the bathymetric survey of the sites. This approach was adopted to minimize the effects of depth on the sedimentological patterns retrieved. Stations were distributed in three groups: 1) inside the aquaculture area, representing the substrate directly affected by culture biodeposition (7 stations at each site); 2) adjacent profile (external profile 1), located $30 \mathrm{~m}$ from the culture structures' boundary, representing the substrate affected by the potential indirect influences of the culture (10 stations at the Alto Ribeirão site and 15 stations at Museu Beach), and 3) external profile 2, at a distance of $75 \mathrm{~m}$, representing an area supposed to lie beyond the culture's influence (10 stations at Alto Ribeirão and 14 at Museu Beach).

The biosedimetological campaign was undertaken on March $28^{\text {th }}, 2007$, at Museum Beach and May $15^{\text {th }}, 2007$, at Alto Ribeirão. Surface sediment samples (first $10 \mathrm{~cm}$ ) were obtained with a Van-Veen grab. The samples were immediately separated into sub-samples for foraminiferal, grain size and geochemical analysis. The biological subsamples were collected in the uppermost layer of the sediment (about $2 \mathrm{~cm}$ ) and preserved in a solution of Bengal Rose (WALTON, 1952) diluted in $40 \%$ alcohol.

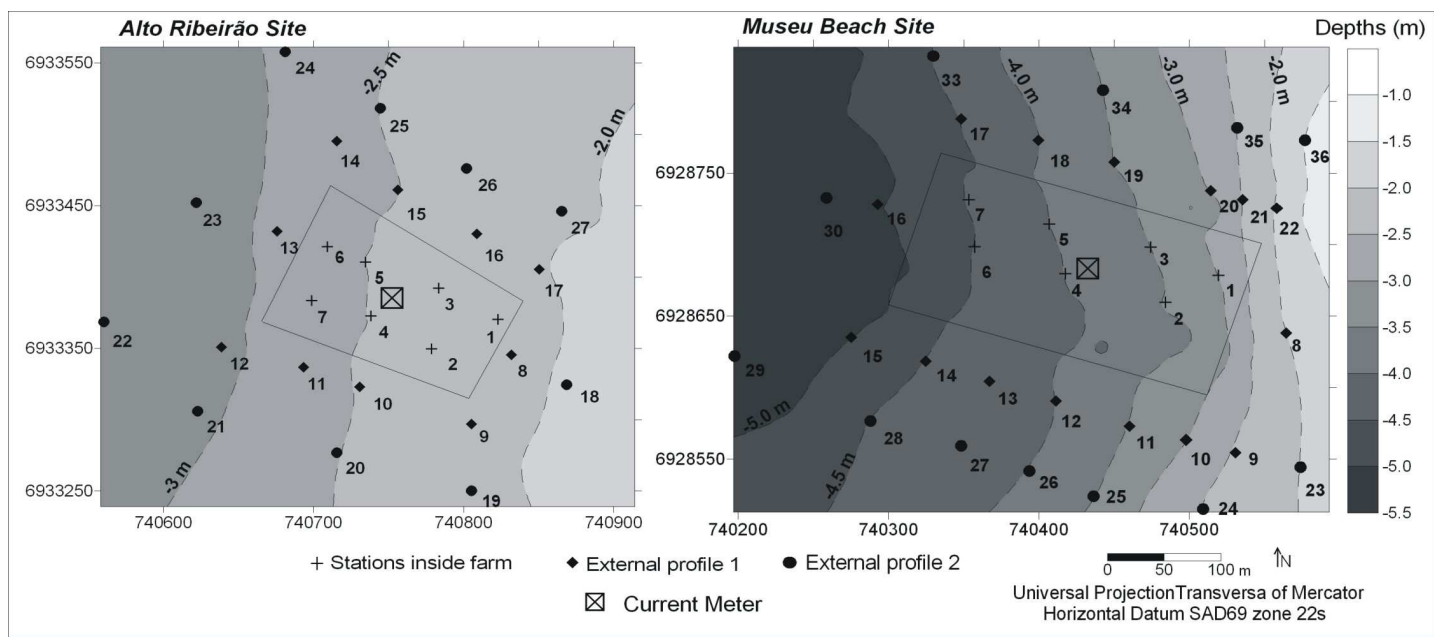

Fig. 2. Sampling design with the locations of current meter mooring and biosedimentological stations. Solid lines represent farms' boundary, and dashed lines indicate the contour depths plotted at $0.5 \mathrm{~m}$ intervals. 
Laboratory Analysis

The foraminiferal fauna was analyzed from a sub-sample of $50 \mathrm{~cm}^{3}$ of wet sediment. The samples were subjected to wet sieving with a $0.63 \mu \mathrm{m}$ mesh to wash out fine sediments and to a floating process with trichloroethylene $\left(\mathrm{C}_{2} \mathrm{HC}_{13}\right)$ to decant heavy quartz grains and consequently concentrate the foraminiferal tests. All the selected fractions were analyzed for a quantification of faunistic density. The first 150 specimens identified under a binocular microscope (ZEISS-Discovery V12) were used for the studies of assemblage composition and ecological diversity index. The taxonomic studies adopted the generic classification of Loeblich and Tappan (1988). To establish a limit for the spatial analyses, we chose to examine the total assemblage (living+dead tests), which can provide information on population composition over the previous few months (DEBENAY; GUILLOU, 2002). Besides density and diversity indexes (PIELOU, 1969), other ecological descriptors such as the percentage of pyritized tests, relative frequency of species and groups recognized as indicators of benthic organic enrichment (e.g. Ammonia tepida, buliminids and bolivinids), living:total ratio and test size, were also analyzed. The test size was determined by randomly selecting 30 individuals of the Ammonia genus, and measuring their widest spiral axis, using microscope photographs and AxionVision software (Inc. Zeiss).

Grain size, total organic matter and biodetritic carbonate content were examined in subsamples of $30 \mathrm{~g}$ of dried sediment. Before sedimentological analysis, the samples were washed to eliminate salinity and dried in an oven at $60^{\circ} \mathrm{C}$. The grain size fractions were determined by mechanical dry sieving (sands) and the pipette method (muds). The total organic matter content was obtained by treating with $30 \% \mathrm{H}_{2} \mathrm{O}_{2}$, and biodetritic carbonate by treatment with $10 \% \mathrm{HCl}$, in accordance with the methods described in Gross (1971). Organic carbon and total nitrogen were analyzed in a separate subsample, using a LECO CHN 2000 Auto Analyzer, after the removal of the carbonate fraction by reaction with hydrochloride acid (1 M).

\section{Data Analysis}

The bathymetry data, after corrections related to the local tidal variation and instrument precision, were imported to Surfer (Golden Software) spatial data analysis software. A regular grid (Digital Terrain Model) was obtained by interpolation using the geostatistical kriging method, considering the spatial covariance and distance of the points sampled.

Statistical analyses of grain size data (mean grain size, sorting, skewness, and kurtosis) were made using SYSGRAN software, in accordance with the classifications of Shepard (1954) and Folk and Ward (1957). With the exception of foraminifera density (total number of tests in $50 \mathrm{~cm}^{3}$ of sediment) and species richness (S), the other ecological indexes (Shannon's diversity (H'), Pielou's evenness (J') and Simpson's dominance (D')) were calculated using the MVSP (Multivariate Statistical Package) software. Differences between the three station groups (inside culture areas, adjacent and external profiles) were tested using the Kruskal-Wallis non-parametric ANOVA (H test).

The Spearman's rank correlation coefficient $(r)$ was applied to determine the relationships between the biosedimentological descriptors, and the local hydrodynamics and geomorphology conditions. Qmode hierarchical analysis was applied to identify subenvironments, grouping the stations with corresponding prevalent ecological conditions, using the Euclidian distance matrix and Ward's minimum variance clustering method.

\section{RESULTS}

\section{Hydrodynamics and Physical-Chemical Parameters}

Winds measured during the Alto Ribeirão survey were predominantly southwesterly with a mean speed of $11 \pm 6 \mathrm{~km} \cdot \mathrm{h}^{-1}$. The mean tidal current during the complete cycle was $1.5 \pm 0.9 \mathrm{~cm} . \mathrm{s}^{-1}$, and the strongest currents were observed during the flood period. The current values were relatively homogeneous throughout the water column. The direction of the main flux was northeastwards, i.e., that of the flood tide. Physical-chemical parameters were vertically homogeneous, due to the shallowness of the station $(2.7 \mathrm{~m})$ and the wind-forced turbulence during the survey. Salinity underwent little oscillation (32.5 to 33.7), and dissolved oxygen was the only parameter that demonstrated some vertical stratification, with a minimum of $3.4 \mathrm{mg} . \mathrm{L}^{-1}$ near the bottom and a maximum of $7.2 \mathrm{mg} . \mathrm{L}^{-1}$ at the surface. A turbidity peak of 9 NTU was recorded in the nearbottom water during the flood tide, associated with the strongest bottom current measured - of $11.1 \mathrm{~cm} \cdot \mathrm{s}^{-1}$.

At the Museu Beach, winds moved at the same mean speed $\left(11 \pm 6 \mathrm{~km} \cdot \mathrm{h}^{-1}\right)$ as observed at Alto Ribeirão, though the tidal currents, also measured during a full tidal cycle, were stronger, with a mean velocity of $3 \pm 2 \mathrm{~cm} \cdot \mathrm{s}^{-1}$. Current intensities varied along the water column, with the greatest values being associated with deeper waters $\left(13 \pm 8 \mathrm{~cm} \cdot \mathrm{s}^{-1}\right)$. Physicalchemical parameters also showed vertical stratifications, and salinity demonstrated higher local penetration of marine waters, varying from 32.2 to 35.8. Dissolved oxygen showed less vertical variation, with a minimum value of $4.6 \mathrm{mg} . \mathrm{L}^{-1}$ near the bottom 
and a maximum of $7.2 \mathrm{mg} . \mathrm{L}^{-1}$ at the surface, despite the greater depths. A maximum turbidity of 26 NTU was recorded in near-bottom waters during flood tide, and was associated with the strongest current measured, $47 \mathrm{~cm} \cdot \mathrm{s}^{-1}$.

\section{Bathymetry}

Depths at Alto Ribeirão varied from $1.8 \mathrm{~m}$ near the coastline, to $3.5 \mathrm{~m}$ towards the inner zone of the Bay. In the culture area it ranged from 2 to $3 \mathrm{~m}$, and the underwater topography showed a slight salience in the culture's oldest and shallowest sector (Fig. 3). The Museu Beach presented depths ranging from $1.2 \mathrm{~m}$ to $5.5 \mathrm{~m}$, also following the gradient from shore to the inner bay. The deeper morphology of this site is characterized by one of the bay's circulation channels that passes through. A small channel perpendicular to the coast, possibly associated with a former drainage system established under lower sealevel conditions, was also observed at the southern boundary of the area. Unlike the Alto Ribeirão site, no evidence of any topographic salience was found within the culture area (Fig. 3).

\section{Sedimentological Features}

At the Alto Ribeirão site, the sediments were predominantly composed of fine sand, although some stations located below the culture structures (longlines), especially in the oldest and shallowest sector, were also composed of finer sediments of a blackish color. The granulometric distribution presented a general pattern of gravel and coarse sands dominating the shallow areas near the coastline, and muddy sediments occurring in deeper areas towards the inner bay zone (Fig. 3). The heterogeneous grain size distribution induced by natural conditions made the determination of the impact of the shellfish culture more difficult because the area was originally a mosaic of sediment patches. Among the sedimentological features analyzed and presented in Table 1, only the $\mathrm{C}: \mathrm{N}$ ratio was significantly different inside and outside the culture area, with slightly lower values inside the farm.

At Museu Beach, the predominant sediment was silty-mud. Although this site also presented a gradient from coarse to finer sediments towards the middle of the bay, it was characterized by a more homogeneous sedimentological pattern which helped to distinguish between the sediments inside from those outside the culture area. Four features were significantly different in the spatial distribution due to the presence of the shellfish culture: sediment sorting, skewness, nitrogen content and percentage of biodetritic carbonates. The stations located inside the culture area had more poorly selected grains, higher skewness of grain distribution, lower percentages of nitrogen and higher percentages of biodetritic carbonates, than the stations located outside (Table 1).

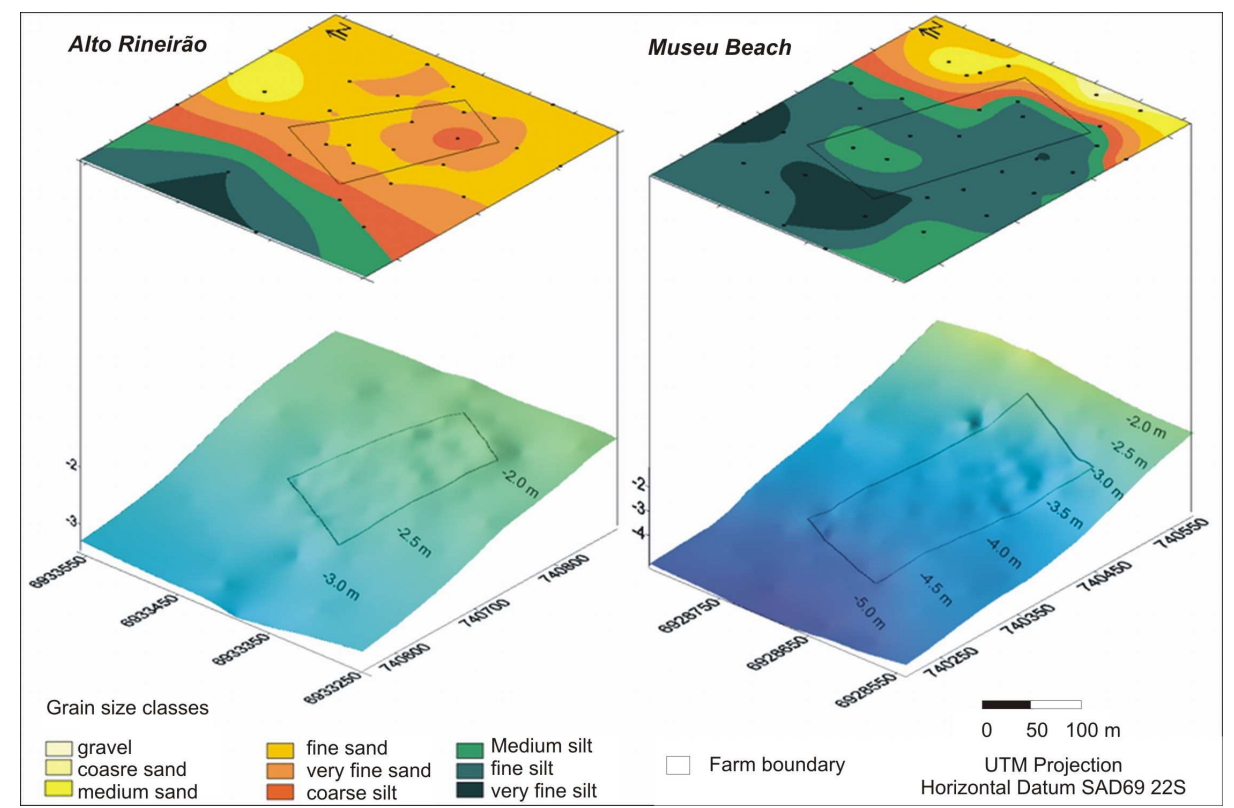

Fig. 3. Digital Terrain Model (DTM) associated with grain size classified maps demonstrating the seafloor geomorphology and sediment distribution of Alto Ribeirão and Museu Beach. 
Table 1. Mean and standard deviation of sedimentological features in each group of stations from both sites. "Inside" corresponds to the area right below the culture $(n=7)$; "adjacent" is the radial profile 30 meters from the farm boundary ( $\mathrm{n}=10$ and 15, for Alto Ribeirão and Museu Beach); and "outside" is the second radial profile 75 meters away (n=10 and 14, for Alto Ribeirão and Museu Beach).

\begin{tabular}{|c|c|c|c|c|c|c|c|c|c|c|c|c|}
\hline \multirow[b]{3}{*}{ Gravel (\%) } & \multicolumn{6}{|c|}{ Alto Ribeirão } & \multicolumn{6}{|c|}{ Museu Beach } \\
\hline & \multicolumn{2}{|c|}{ Inside } & \multicolumn{2}{|c|}{ Adjacent } & \multicolumn{2}{|c|}{ Outside } & \multicolumn{2}{|c|}{ Inside } & \multicolumn{2}{|c|}{ Adjacent } & \multicolumn{2}{|c|}{ Outside } \\
\hline & 2 & \pm 2 & 1 & \pm 1 & 4 & \pm 4 & 0 & \pm 0 & 5 & \pm 14 & 2 & \pm 5 \\
\hline Sand (\%) & 86 & \pm 6 & 85 & \pm 7 & 67 & \pm 34 & 39 & \pm 14 & 31 & \pm 34 & 28 & \pm 35 \\
\hline Silt (\%) & 6 & \pm 5 & 8 & \pm 5 & 20 & \pm 26 & 47 & \pm 11 & 50 & \pm 34 & 61 & \pm 37 \\
\hline Clay (\%) & 6 & \pm 2 & 6 & \pm 14 & 9 & \pm 30 & 14 & \pm 7 & 15 & \pm 15 & 9 & \pm 11 \\
\hline Mud (\%) & 12 & \pm 7 & 14 & \pm 8 & 30 & \pm 36 & 61 & \pm 14 & 64 & \pm 39 & 70 & \pm 38 \\
\hline $\mathrm{MD}^{\mathrm{a}}$ (phi) & 2.8 & \pm 0.6 & 3.0 & \pm 0.6 & 3.3 & \pm 1.9 & 5.2 & \pm 0.7 & 4.8 & \pm 2.4 & 4.8 & \pm 2.1 \\
\hline $\mathrm{MZ}^{\mathrm{b}}$ (phi) & 2.7 & \pm 0.1 & 2.8 & \pm 0.2 & 3.2 & \pm 1.7 & 4.6 & \pm 0.8 & 4.7 & \pm 2.6 & 4.8 & \pm 2.1 \\
\hline $\mathrm{SD}^{\mathrm{c}}$ (phi) & 1.6 & \pm 0.4 & 1.5 & \pm 0.4 & 1.7 & \pm 0.3 & 2.2 & $\pm 0.2^{1}$ & 1.7 & \pm 0.5 & 1.5 & \pm 0.5 \\
\hline $\mathrm{SK}^{\mathrm{d}}$ & 0.2 & \pm 0.4 & 0.3 & \pm 0.3 & 0.2 & \pm 0.3 & 0.3 & \pm 0.2 & 0.1 & \pm 0.6 & 0.0 & \pm 0.3 \\
\hline $\mathrm{KG}^{\mathrm{e}}$ & 3 & \pm 1 & 3 & \pm 1 & 2 & \pm 1 & 0.9 & \pm 0.1 & 1.1 & \pm 0.6 & 1.0 & \pm 0.5 \\
\hline $\operatorname{TOM}^{\mathrm{f}}(\%)$ & 0.5 & \pm 0.8 & 0.6 & \pm 0.5 & 1 & \pm 1.4 & 4 & \pm 1 & 3 & \pm 2 & 5 & \pm 3 \\
\hline$C^{g}(\mu g)$ & 0.4 & \pm 0.3 & 0.3 & \pm 0.1 & 0.7 & \pm 0.6 & 1.3 & \pm 0.1 & 1.4 & \pm 0.2 & 1.5 & \pm 0.1 \\
\hline $\mathrm{N}^{\mathrm{h}}(\mu \mathrm{g})$ & 0.07 & \pm 0.05 & 0.06 & \pm 0.03 & 0.14 & \pm 0.11 & 0.23 & \pm 0.02 & 0.26 & \pm 0.02 & 0.26 & \pm 0.02 \\
\hline $\mathrm{C}: \mathrm{N}^{\mathrm{i}}$ & 5.2 & \pm 0.4 & 5.5 & \pm 0.1 & 5.6 & \pm 0.2 & 5.4 & \pm 0.1 & 5.5 & \pm 0.2 & 5.5 & \pm 0.2 \\
\hline$S(\mu g)^{j}$ & 0 & \pm 0 & 0 & \pm 0 & 0.2 & \pm 0.5 & 0.2 & \pm 0.4 & 0.2 & \pm 0.4 & 0.6 & \pm 0.5 \\
\hline $\mathrm{CaCO}_{3}{ }^{\mathrm{k}}(\%)$ & 6 & \pm 4 & 5 & \pm 2 & 8 & \pm 5 & 14 & \pm 3 & 10 & \pm 5 & 10 & \pm 2 \\
\hline
\end{tabular}

${ }^{a}$ mean grain size; ${ }^{b}$ medium grain size; ${ }^{c}$ sediment sorting; ${ }^{d}$ skewness; ${ }^{\mathrm{e}}$ kurtosis; ${ }^{\mathrm{f}}$ total organic matter; ${ }^{\mathrm{g}}$ carbon; ${ }^{\mathrm{h}}$ nitrogen; ${ }^{\mathrm{i}}$ carbon:nitrogen ratio; ${ }^{\mathrm{j}}$ sulfur; ${ }^{\mathrm{k}}$ biodetritic carbonate.

$* *{ }^{1}$ highlighted $\mathrm{H}$ test, significant differences (at $\mathrm{p}<0.05$ ).

Foraminifera Bioindicators

The most dominant species at Alto Ribeirão was Ammonia tepida, representing $15 \%$ of the total population. The mean density of this area was 5095 \pm 2875 ind. $/ 50 \mathrm{cc}$, and richness was $27 \pm 4$. Some ecological descriptors seemed to reveal slight differences between the area directly beneath the culture structures and the external points. The area inside the culture zone demonstrated an increase in the abundance of Ammonia tepida, lower total density, richness and diversity indexes and a higher dominance index, than did the adjacent areas or those outside the farm boundaries (Fig. 4). A greater percentage of pyritized tests was also observed inside the culture area. However, of the ecological descriptors analyzed, only the mean test size and living:total ratio showed statistically significant differences in the ANOVA $\mathrm{H}$ test $(p<0.05)$, with a lower mean test size and higher living:total ratio beneath the culture structures (Fig. 4).

At Museu Beach, Buliminella elegantissima was the most dominant species, accounting for $27 \%$ of the total population. The mean estimated density was of $2775 \pm 2381 \mathrm{ind} / 50 \mathrm{cc}$ and species richness was 30 \pm 5 . Some ecological descriptors showed slight, though significant differences in the ANOVA H test $(p<0.05)$ between the culture and outside areas. The culture area had higher total density, frequencies of the buliminids and bolivinids (suborder Rotaliina), percentage of pyritized tests and living:total population ratio, as well as a lower frequency of Ammonia parkinsoniana and mean test size. The diversity indexes were not significantly different, but did show some interesting trends, such as a higher richness index beneath the culture area, though also with a higher dominance (Fig. 4).

\section{Correlation Analysis}

The correlation analysis made it possible to evaluate the degree of dependence between the variables and to better comprehend their spatial distribution in the environment. Coarser sediments were positively correlated with an increase in the relative frequency of porcelaneous tests (suborder Miliolina) $(r=0.47)$, estimated density $(r=0.47)$, diversity index $(r=0.45)$, evenness $(r=0.47)$, mean test size $(r=0.69)$ and living:total ratio $(r=0.61)$. 

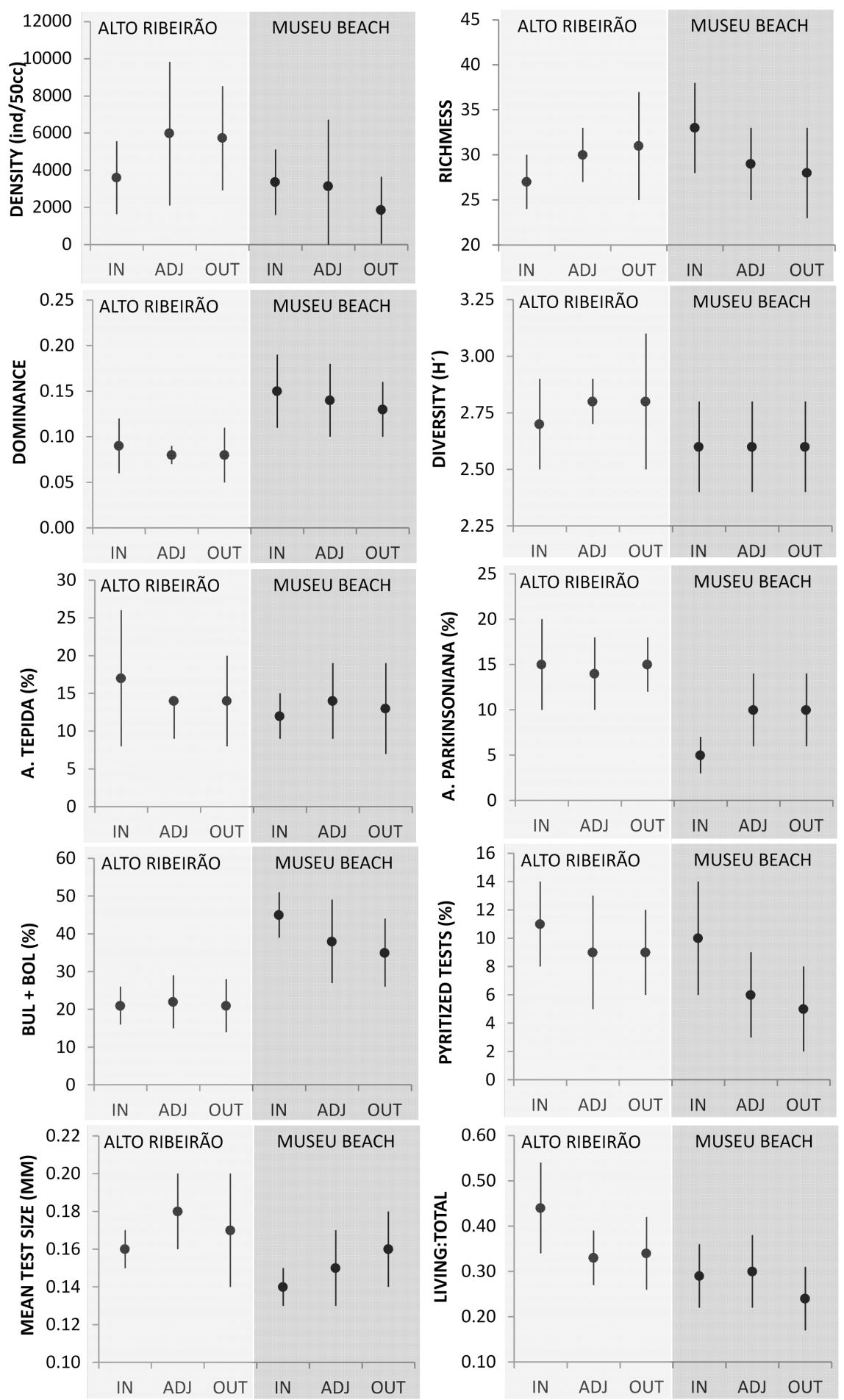

Fig. 4. Statistical means and standard deviation of biological descriptors of the foraminiferal fauna: inside the farm (IN), in the adjacent area (ADJ) and external most profile (OUT). A. tepida, A. parkinsoniana and $\mathrm{Bul}+\mathrm{Bol}$ are the relative frequency $(\%)$ of Ammonia tepida, Ammonia parkinsoniana and buliminids + bolivinids, respectively. 
Muddy sediments correlated positively with total organic matter $(r=0.88)$, organic carbon and nitrogen ( $r=0.67$ and 0.76 , respectively), biodetritic carbonate $(r=0.64)$, relative frequency of agglutinated species $(r=0.34)$, frequency of buliminids and bolivinids $(r=0.72)$ and dominance index $(r=0.69)$. Negative correlations were observed between the relative frequency of Ammonia tepida and richness ( $r$ $=-0.38)$ and the diversity index $(r=-0.40)$.

\section{Biosedimentological Sub-environments}

It was possible to define subenvironments within the area of the sites studied, using the Hierarchical Cluster Analysis (Q mode), that corresponded to the prevailing biosedimentological conditions. Alto Ribeirão presented a more heterogeneous spatial pattern and could be divided into four sub-environments: 1- seabed directly influenced by the culture, 2- shallow areas with gravel and sandy sediments, 3- transitional zone, and 4deeper areas with muddy sediments towards the inner bay (Fig. 5 and Table 2). Sub-environment 1, composed mainly of the stations within the oldest and shallowest sector of the Alto Ribeirão farm (Fig. 5), was characterized by higher levels of living: total ratio, dominance of Ammonia tepida and smaller test size (Table 2). Two external stations were also grouped within this sub-environment: one in profile 1 , towards the south, and the other in profile $2(75 \mathrm{~m}$ from the farm) towards the north. Northwards from the sampling site, there is a small river and a mangrove system which may also be contributing to the organic loading at that particular station. The two stations located in the deepest and most recent sector of the farm (with only five months of production) were not grouped in the culture sub-environment, but rather in the transition zone sub-environment.

Museu Beach was only divided into two subenvironments, corresponding to the shallow area following the coastline (sub-environment 5) and the deeper area towards the inner bay zone (subenvironment 6) (Fig. 5 and Table 2). In a multivariate integrated approach, the area directly influenced by shellfish culture at this site did not characterize a subenvironment differentiated from the adjacent area.

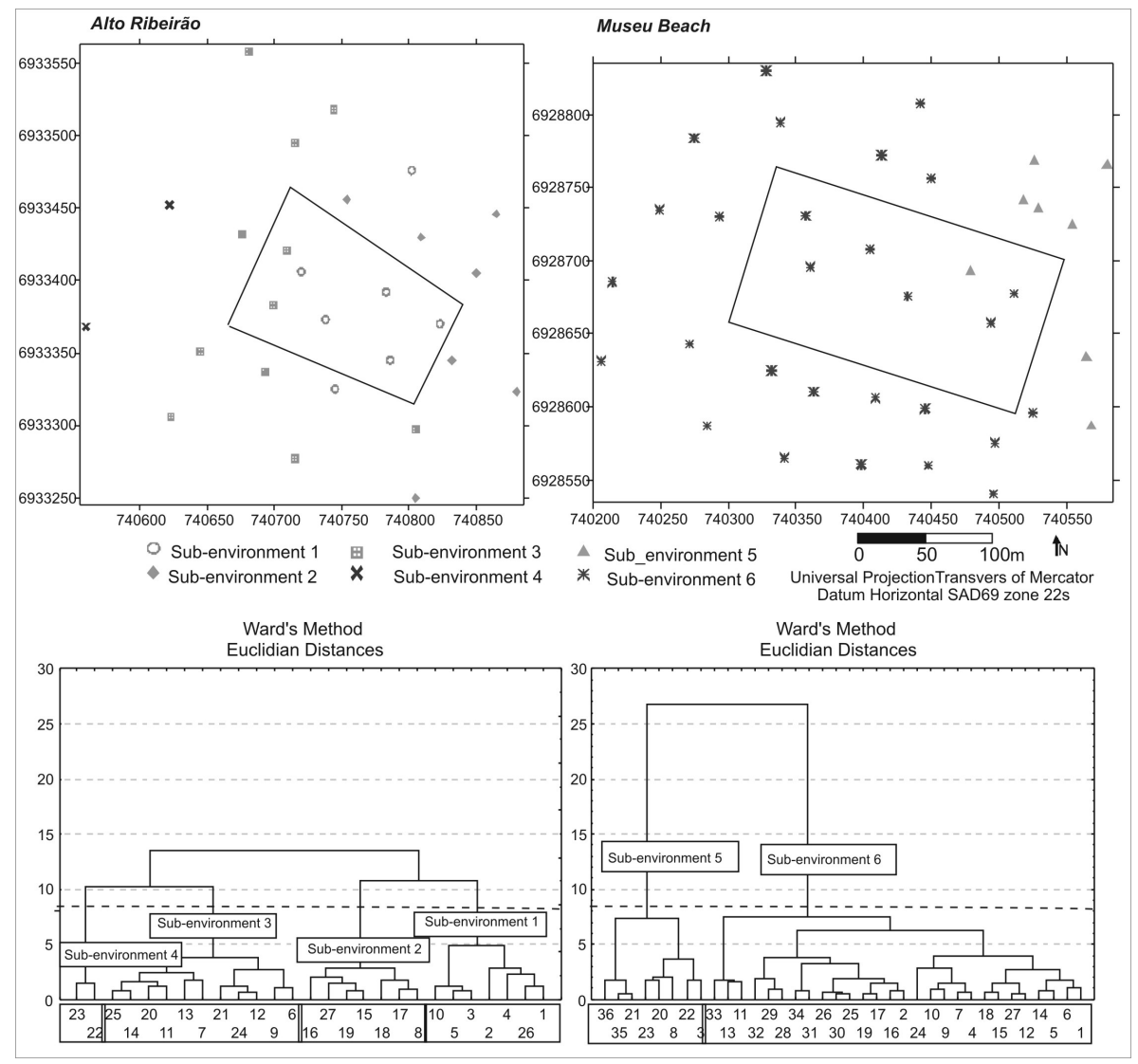

Fig. 5. Dendrogram showing the classification of the two sites into six sub-environments and the respective groups' spatial distributions. 
Table 2. Mean and standard deviation of biosedimentological features in the sub-environments identified at both sites.

\begin{tabular}{lcccccc}
\hline \hline & $\begin{array}{c}\text { Sub 1 } \\
\text { (biodeposit) }\end{array}$ & $\begin{array}{c}\text { Sub 2 } \\
\text { (coastline) }\end{array}$ & $\begin{array}{c}\text { Sub 3 } \\
\text { (transition) }\end{array}$ & $\begin{array}{c}\text { Sub 4 } \\
\text { (deeper areas) }\end{array}$ & $\begin{array}{c}\text { Sub 5 } \\
\text { (coast) }\end{array}$ & $\begin{array}{c}\text { Sub 6 } \\
\text { (channel) }\end{array}$ \\
\hline Mud (\%) & $11 \pm 7$ & $9 \pm 1$ & $16 \pm 10$ & $95 \pm 5$ & $11 \pm 13$ & $81 \pm 20$ \\
${\text { A. } \text { tepida }^{\mathrm{a}}}^{\text {Bul+Bol }}$ & $20 \pm 6$ & $12 \pm 4$ & $12 \pm 5$ & $24 \pm 6$ & $14 \pm 7$ & $13 \pm 5$ \\
Test size $^{\mathrm{c}}$ & $18 \pm 3$ & $14 \pm 3$ & $28 \pm 3$ & $27 \pm 0$ & $23 \pm 6$ & $43 \pm 5$ \\
Living:total & $0.16 \pm 0.01$ & $0.20 \pm 0.01$ & $0.17 \pm 0.01$ & $0.15 \pm 0.00$ & $0.18 \pm 0.02$ & $0.14 \pm 0.01$ \\
\hline
\end{tabular}

${ }^{\mathrm{a}}$ frequency of A. tepida; ${ }^{\mathrm{b}}$ frequency of buliminids and bolivinids; ${ }^{\mathrm{c}}$ Mean diameter of test size in mm.

\section{Discussion}

The Alto Ribeirão site is located on a protected bight in the central sector of South Bay, normally subject to weak hydrodynamic conditions (MELO et al., 1997). Nevertheless, because field sampling was performed under relatively extreme conditions of persistent southerly winds and spring tide, the combination of these forces increased currents and wave action, causing vertical mixing and some resuspension of seabed sediments. However, even under these intentionally analyzed extreme conditions, Alto Ribeirão was still characterized by relatively low current flows. Thus, under high energetic conditions this site is possibly influenced primarily by local wind generated waves which promote seabed resuspension and vertical mixing, but not by high current flows which could actively disperse the resuspended sediments over extensive areas. Schettini et al. (2006) have also discussed the influence of waves and currents in the resuspension of biodeposits at other aquaculture sites located on the Santa Catarina coast. It seems that these eventual high energy events are more likely to act on recent post-settled particles of the upper layer of the seabed since compacted biodetritis accumulated over longer time periods is less likely to be subject to resuspension (CROMEY et al., 2002).

Hartstein and Stevens (2005) observe that major forces occurring during periodic events can act in the resuspension and reduction of the biodeposit but that they may not be sufficient to prevent its formation if normal conditions of tidal currents allow high sedimentation in protected areas (CHAMBERLAIN et al., 2001). Additionally, wind generated waves can resuspend biodetritic sediments, but only stronger currents can promote the dispersion of the particles to distant areas (SCHETTINI et al. , 2006). As Alto Ribeirão is subject to weak tidal currents, even under extreme conditions, it presents favorable conditions for biodeposit formation beneath culture systems. Barg (1992) also emphasizes that biodeposit resuspension due to intensive periodic events may not be of much benefit to the environment if it liberates toxic compounds into the water column when the source presents eutrophic processes of sulfur and nitrogen reduction.

Museu Beach, which is located in a more exposed zone, closer to South Bay's opening to the Atlantic Ocean, presented significantly stronger currents during the cycle studied. The bathymetric survey revealed the presence of a circulation channel (parallel to the coast) that may also control the stronger bottom currents observed at this site. According to -Cromey et al. (2002) the critical velocity of deep currents to resuspend and disperse biodetritis is $9.5 \mathrm{~cm} . \mathrm{s}^{-1}$. Bottom currents recorded at the Museu Beach during flood tide attained even higher values and were associated with sediment resuspension, as indicated by the high turbidity observed. During high energy hydrodynamic events, the bottom currents are therefore likely capable of resuspending and dispersing sediments accumulated beneath the culture structures at Museu Beach. However, dominant conditions must also be studied in order to determine the main hydrodynamic regime of this site. We may, nevertheless, classify Museu Beach as a more dispersive site than Alto Ribeirão based on its location and the stronger currents observed during the tidal cycle studied.

Seafloor topography at both sites presented a naturally steep configuration, sloping down from the coastline to the deeper inner bay zone. However, a slight elevation was observed in the oldest and shallowest sector of the Alto Ribeirão culture area, suggesting the formation of a local biodeposit layer. Pronounced saliencies under shellfish cultures due to the presence of a biodeposit layer have been reported in other regions with more intensive production (MATTSON; LINDÉN, 1983; OTERO et al., 2006). The Alto Ribeirão site has relatively shallow depths associated with weak hydrodynamics which, according to Jusup et al. (2007), reduces the area of particle dispersion and favors biodeposition directly beneath culture operations. On the other hand, Museu Beach did not present any salient layer, possibly due to the 
greater depths and stronger hydrodynamics, which amplify the dispersion area of biodeposition, minimizing accumulation beneath the culture structures.

However, even though it is considered a depositioning site, Alto Ribeirão gave only slight indications of biosedimentological alterations on the seabed directly influenced by the culture structure. The sedimentological heterogeneity and great influence of the bathymetric gradient on the sediment patterns made it difficult to identify the differences. The most evident alteration of the sediment composition within the culture area were the reduced values of the C:N ratio. Mussel biodeposits are known to be rich in organic nitrogen, which may be used as a tracer of this type of enrichment in coastal systems (KASPAR et al., 1984; GRENZ et al., 1990). Lower values of C:N related to mussel biodeposits have also been reported by Chamberlain et al. (2001), Hartstein and Rowden (2004), Otero et al. (2006) and Bonetti et al. (2006a). At Museu Beach, no significant differences in the C:N ratio were found between the station groups, but there were other sedimentological descriptors that presented some differences, including the poor sorting of grain sizes, higher skewness of grain distribution and the higher percentage of biodetritic carbonate. Besides biodeposition, the structures of the culture systems may also modify the sedimentation patterns of suspended material from the natural environment, affecting the areas surrounding the culture (BOYD; HEASMAN, 1998). Thus, even if there is little promotion of organic accumulation by biodeposition on the seabed, the culture structures can interfere in the local sedimentological pattern. This seems to be the major cause of the sedimentological alterations encountered at the Museu Beach site.

Higher biodetritic carbonate levels encountered beneath shellfish cultures may be associated with the fragments of the broken shells that fall from the culture structures, as well as with the enhancement of benthic biological production induced by the organic flux (GRANT et al., 1995). This last explanation seems to be the most suitable for Museu Beach since only a few fragments of cultured mussel and oyster shells were observed beneath this farm, while the meiofauna abundance was very important. Similar patterns of biodetritic carbonate have been reported by Bonetti et al. (2006a) at shellfish cultures in South Bay, classified as areas with moderate organic enrichment.

Foraminiferal fauna showed important responses to the impacts of shellfish culture, even without showing major alterations in the community structure. At both sites within the culture area, populations with smaller mean diameter tests and higher living:total population ratios were observed. The smaller mean test size suggests a more competitive environment, possibly indicating changes in reproduction strategy and hypoxic trends (NICHOLS, 1974; SEN GUPTA;MACHAINCASTILLO, 1993). The increase in the importance of the living to total population can be associated with high local sedimentation rates (NICHOLS, 1974; SETTY, 1982) that might be related to the culture biodeposition. In this case, dead tests are buried more rapidly, which explains their smaller proportion than that of the living tests. Other ecological features demonstrated the different behaviors of the fauna at each site, which suggests varying degrees of impact. Within the culture area of the Alto Ribeirão, lower foraminifera densities, richness and evenness indexes were found, indicating a more restricted environment (ODUM, 1983; GRALL; CHAUVAUD, 2002; BURONE et al., 2006). Similar trends of the foraminiferal fauna were attested by Grant et al. (1995) and Scott et al. (1995) at aquaculture sites in Canada (Nova Scotia). The higher dominance of Ammonia tepida under culture sites, as observed at the Alto Ribeirão site, was also observed by Boucheti et al. -2006 at mussel farms on the central-west coast of France. This species is a potential indicator of organic enrichment (ALVE, 1995; BURONE et al., 2006), a conclusion which was also supported by the results of the correlation analysis of this present study. At Museu Beach, the higher dominance of groups of buliminids and bolivinids, and the percentage of pyritized tests, may indicate greater hypoxic conditions beneath the culture structures (SEN GUPTA; MACHAIN-CASTILLO, 1993; ALVE, 1995; BURONE; PIRES-VANIN, 2006). However, in this case these descriptors, that indicate restrictive ecological conditions, were not just limited to the culture area, but also had a highly significant correlation with the natural spatial distribution of muddy sediments, dominant in the deeper areas of the bay. Thus, it is that the environment itself is naturally ecologically restricted. Further, the foraminiferal fauna also presented some positive responses within the Museu Beach culture area, with higher density population and richness. This may suggest that the culture biodeposition at this site induces a flux that stimulates benthic biological productivity, without exceeding the levels of environmental assimilation that would affect the benthos negatively (GRANT et al., 1995). However, a significant reduction of the Ammonia parkinsoniana population beneath the culture area was also observed, which may indicate some level of stress at this site (SAMIR, 2000).

Multivariate techniques applied to this study allowed for the integration of some selected descriptors and for the mapping of sectors under different sedimentological and ecological conditions. Both sites had a sub-environment that characterized the marginal shore areas as being of high benthic 
productivity, possibly due to continental inputs, and strongly influenced by wind generated waves that constantly rework the bottom sediments. Another common sub-environment was related to the deeper inner bay zone, characterized by dominance of muddy sediments in a more restricted ecological environment. This following of the natural bathymetric and inward gradients is also observed in other coastal embayment environments (BURONE et al., 2003; BURONE; PIRES-VANIN, 2006). Despite some statistical differences encountered between the stations at the two sites, through a one-way analysis of variance, a sub-environment characterized by the conditions prevailing in an area directly influenced by the culture structure, and therefore indicating the presence of a biodeposit layer, was only identified at the more protected site (Alto Ribeirão). The main descriptors that characterized this culture-influenced subenvironment were the living:total ratio, the mean test size and dominance of Ammonia tepida. This area was coincident with the salience observed in the Digital Terrain Model and the blackish sediment observed during the sampling collection.

The findings of this present study corroborate the idea that the shellfish culture at the sites studied promotes minor effects on the seabed substrate, in accord with other studies that have found little or no effects of suspended shellfish aquaculture on the benthic layer (GRANT et al., 1995; SCOTT et al., 1995; CRANDFORD et al., 2003). Nevertheless, some differences were observed between the depositioning and the more dispersive sites, evidencing different degrees of impact. This is also in agreement with the results of other studies which have analyzed the differences between sites with different local environmental conditions (CHAMBERLAIN et al., 2001; HARTSTEIN; ROWDEN, 2004).

\section{Conclusions}

The minor biosedimentological alterations caused by shellfish culture biodepositioning observed at both sites could be due to many factors, such as the small and relatively recent production areas, higher biological assimilation in subtropical waters, and others factors which require investigation in future studies to create a better understanding of the interactions between the culture and environmental responses.

The primary controlling factors determining the impact levels of the shellfish cultures on the benthic layer seem to be the seabed topography and hydrodynamics. Greater depths and stronger bottom currents appeared to be effective in preventing, or minimizing, the formation of a biodeposit layer beneath the culture and consequently reducing the impact on benthic communities.
Although the natural environmental gradient made the impact evaluation more difficult, especially due to the high heterogeneity of the biosedimentological patterns, some of the descriptors used were efficient to synthesize spatial patterns and identify culture impacts. Sedimentological variables such as sediment sorting, skewness and percentage of biodetritic carbonates responded well for the most exposed site, but were not significant for the other. The ecological descriptors, on the other hand, seemed to be more representative of different environmental conditions and we recommend the use of: (1): mean test size, (2) abundance of Ammonia tepida and (3) living:total ratio, to monitor the impact of marine aquaculture systems, addressing also different aspects of spatial and temporal variability. The integration of these descriptors through multivariate techniques and spatial analysis allowed the identification of areas with specific benthic conditions within the aquaculture sites. The site located in a more sheltered bight, subject to weaker hydrodynamic conditions and shallower depths, showed slightly more negative alterations, with indications of a local biodeposit layer beneath the culture structures. On the other hand, the site located in a more dispersive area showed minor alterations due to shellfish farming with no biodeposit layer. These findings reinforce the importance of taking local environmental criteria into consideration in site selection for new aquaculture areas.

\section{ACKNOWLEDGMENTS}

We would like to thank Dr. Letícia Burone (of the Oceanographic Institute of São Paulo University) who helped us with the discussion of the foraminiferal distribution, Dr. Luiz Augusto dos Santos Madureira (of the Department of Chemistry of the Federal University of Santa Catarina) for his support with the geochemical analysis, and also the owners of the shellfish farms studied who allowed us to undertake this study in their respective areas, providing us with all the necessary support.

\section{REFERENCES}

ALVE, E. Benthic foraminiferal responses to estuarine pollution: a Review. J. foram. Res., v. 25, p. 190-203, 1995.

ANGEL, D. L.; VERGHESE, S.; LEE, J. J.; SALEH, A. M.; ZUBER, D.,; LINDELL, D.; SYMONS, A. Impact of a net cage fish farm on the distribution of benthic foraminifera in the northern Gulf of Eilat (AQABA, Red Sea). J. foram. Res., v. 30, p. 54-65, 2000.

BARG, U. C. Guidelines of the promotion of environmental management of coastal aquaculture development. FAO Fish. tech Pap., n. 328, 122p, 1992. 
BONETTI, C.; BONETTI, J.; BARCELlOS, R. L. Caracterização sedimentar e geoquímica de sistemas de cultivo de moluscos. In: BARROSO, G. F. et al. (Org.). Sistemas de cultivos aquícolas costeiros no Brasil: Recursos, tecnologias e aspectos ambientais e sócioeconômicos. Rio de Janeiro: Museu Nacional, 2006a. Cap. 1

BONETTI, C.; BONETTI, J.; BELTRAME, E. 2006b. The influence of natural and anthropogenic agents in the determination of sedimentary environments at Itapocu estuarine-lagoonal system, Santa Catarina, Brazil. J. coast. Res., SI 39, p. 1762-1766, 2006b. (Proceedings of the International Coastal Symposium, 8. ).

BOUCHET, V. M. P.; SAURIAU, P-G. Influence of oyster culture practices and environmental conditions on the ecological status of intertidal mudflats in the Pertuis Charentais (SW France): A multi-index approach. Mar. Pollut. Bull., vol 56, p. 1898-1912, 2008

BOUCHETI, V.; DEBENAY, J.; SAURIAU, P. 2006. Benthic foraminifera as proxies of temperature impact and dystrophic crisis affecting survival of Pacific oyster Crassostrea gigas (Thunberg) in Marennes-Oléron bay. Anuário do Instituto de Geociências-UFRJ: FORAMS v. 29-1, p. 451-452, 2006.

. BOYD, A. J.; HEASMAN, K. Shellfish mariculture in the Benguela system: water flow patterns within a mussel farm in Saldanha Bay, South Africa. J. Shellfish Res., v. 17, p. 25-32, 1998

BURONE L.; PIRES-VANIN, A. M. Foraminiferal assemblages in Ubatuba Bay south-eastern Brazilian coast. Sci. Mar., vol. 70, p. 203-217, 2006.

BURONE L.; VENTURINI N.; SPRECHMANN P.; VALENTE P. E; MUNIZ P. 2006. Foraminiferal responses to polluted sediments in the Montevideo coastal zone, Uruguay. Mar. Pollut. Bull., v. 52, p. 6173, 2006.

CHAMBERLAIN, J.; FERNANDES, T. F.; READ, P.; NICKELLT. D.; DAVIES, I. M. Impacts of biodeposits from suspended mussel (Mytilus edulis L.) culture on the surrounding surficial sediments. ICES J. Mar. Sci., v. 58, p. 411-416, 2001.

CRANDFORD, C. M.; MACLEOD, C. K. A.; MITCHELL I. M. Effects of shellfish farming on the benthic environment. Aquaculture, v. 224, p. 114-140, 2003.

CROMEY, C. J.; NICKELL, T. C; BLACK, K. D. 2002. DEPOMOD- Modelling the deposition and biological effects of waste solids from marine cage farms. Aquaculture, v. 214, p. 211-239.

DAME, R. F. Ecology of Marine Bivalves: an ecosystem approach. Boca Raton: CRC Press, 1996. 254p. CRC Marine Science Series

DEBENAY, J.P.; GUILLOU J J. Ecological transitions indicated by Foraminiferal Assemblages in Paralic Environments. Estuaries, v. 25, no. 6a , p. 1107-1120, 2002.

EPAGRI - Empresa Agropecuária e Extensão Rural de Santa Catarina. Produção de Moluscos (mexilhões e ostras) em 2009 no Estado de Santa Catarina. 2009. <http://www.epagri.sc.gov >. Accessed on $05^{\text {th }}$ March, 2010 .

FAO- Food and Agriculture Organization of the United Nations. In: Aquaculture News Letter no. 45. Global Conference on Aquaculture 2010, Farming the Waters for Food and People, 27 September, Phuket, Thailand.
FERREIRA J.; MAGALHÃES A. R.. Cultivo de mexilhões. In: POLI, C. R.; POLI, A. T. B.; ANDREATTA, E.; BELTRAME. E. (Ed.). Aquacultura Experiências Brasileiras. Florianópolis: Multitarefa Editora, 2004. p. 221-250.

FOLK, R. L.; WARD, W. C. Brazos river bar: a study in the significance of grain size parameters. J. Sediment. Petrol., v. 27, p. 3-7, 1957.

GRALL, J.; CHAUVAUD, L. Marine eutrofication and benthos: the need for new approaches and concepts. Glob. Change Biol., v. 8, p. 813-830, 2002.

GRANT, J.; HATCHER, A.; SCOTT, D. B.; POCKLINGTON, P.; SCHAFER, C. T.; WINTER, G. A multidisciplinary approach to evaluating benthic impacts of shellfish aquaculture. Estuaries, v. 18, p. 124-144, 1995.

GRENZ, C.; HERMIN, D.; BAUDINET, D.; DAUMUS, R. In situ biogeochemical and bacterial variation of sediments enriched with mussel biodeposits. Hydrobiologia, v. 207, p. 153-160, 1990.

GROSS, M. G. Carbon determination. In: CARVER, R. E. (Ed..) Procedures in Sedimentology Petrology. New York: Wiley Interscience, 1971. p. 49-94.

HARTSTEIN, N. D.; ROWDEN, A. A. Effect of biodeposits from mussel culture on macroinvertebrate assemblages at sites of different hydrodynamic regimes. Mar. Environ. Res., v. 57, p. 339-357, 2004.

HARTSTEIN, N. D.; STEVENS, C. L. Deposition beneath long-line mussel farms. Aquacult. Eng., v. 33, p. 192213, 2005.

JUSUP M.; GECEK S.; LEGOVIC T. Impact of aquacultures on the marine ecosystem: Modelling benthic carbon loading over variable depth. Ecol. Model., v. 200, p. 459-466, 2007.

KASPAR, H. F.; GILLESPIE, P. A.; BOYER, I. C.; MACKENZIE, A. L. Effects of mussel aquaculture on the nitrogen cycle and benthic communities in Kenepru Sound, Marlborough Sounds, New Zealand. Mar. Biol., v. 85 , p. $127-136,1985$.

LOEBLICH, A. R.; TAPPAN, H. Foraminiferal genera and their classification. New York: Van Nostrand Reinhold, 1-2, 1988.

LONGDILL, P. C.;HEALY T. R.; BLACK K. P. An integrated GIS approach for sustainable aquaculture management area site selection. Ocean Coast. Manage., v. 51, p. 612-624, 2008.

MALLET, A. L.; CARVER, C. E.; LANDRY, T. Impact of suspended and off-bottom Eastern oyster culture on the benthic environment in eastern Canada. Aquaculture, v. 255, p. 362-373, 2006.

MATTSON, J.; LINDÉN, O. Benthic macrofauna succession under mussels, Mytilus edulis L. (Bivalvia), cultured on hanging long lines. Sarsia, v. 68, p. 97-102, 1983.

MCKINDSEY, C. W; THEMEYER, H.; LANDRY, T.; SILCERT, W. Review of recent carrying capacity models for bivalve culture and recommendations for research and management. Aquaculture, v. 261, p.451462, 2006.

MELO, E.; MARTINS, R. P.; FRANCO, D. Standing wave tide at Florianópolis Bay (Brazil) and its influence on bay pollution. Anais do Bordomer 97-Amenagement et Protection de L'Environment Littoral, Bordeaux, France, 1997. 
MURRAY, J. W. Ecology and paleocology of benthic foraminifera. London: Logman Scientific \& Technical, 1991. p. 397.

NICHOLS, M. M. 1974. Foraminifera in estuarine classification. In: ODUM, H. T. ; COPELAND, B. J.; MCMAHAN, E. A. (Ed.). Coastal ecological systems of the United States. Washington, D.C.: The Conservation Foundation, 1974. p. 85-103

ODUM, H.T. 1983. System Ecology. New York: Wiley Interscience, 1983. p. 644.

OTERO, X. L; CALVO DE ANTA, R. M.; MACÍAS, F. Sulphur partitioning in sediments and biodeposits below mussel rafts in the Ría de Arousa (Galicia, NW Spain). Mar. environ. Res., v. 61, p. 305-325, 2006.

PIELOU, E. C. 1969. Mathematical Ecology. John Wiley and Sons, 1969

SAMIR, A. M. 2000. The response of benthic foraminifera and ostracodes to various pollution sources: A study from two lagoons in Egypt. J. foram. Res., v. 30, p. 8398, 2000.

SEN GUPTA B. K.; MACHAIN-CASTILLO, A. M..Benthic foraminifera in oxygen-poor habitats. Mar. Micropaleontol., v. 20, p.183-201, 1993.

SETTY, M. G. ANANTHA PADMANABHA. Recent marine microfauna from the Continental Margin, West Coast of India. J. of Sci. Ind. Res. India, v. 41, p. 674 679, 1982.
SCHETTINI, C.A.F.; D'AQUINO, C.A.; CARVALHO, C.E.V. 2006. Fine sediment dynamics under blue mussel aquaculture plots in semi-sheltered bight: the Armação do Itapocoroy, SC, Brazil. J. coast. Res., SI 39 (Proceedings of the 8th International Coastal Symposium), p. 1746 - 1751. Itajaí, SC, Brazil, 2006.

SCOTT, D. B.; SCHAFER, C. T.; HONIG, C. ; YOUNGER D. C. Temporal variations of benthic foraminiferal assemblages under or near aquaculture operations: documentation of impact history. J. foram. Res., v. 25, n.3, p. 224-235, 1995

SHEPARD, F. P. 1954. Nomenclature based on silt-clay ratios. J. sediment. Petrol., v. 9, p. 62-76, 1954.

WALTON, W. R. Techniques for recognition of living foraminifera. Contr. Cushman. Fdn foram. Res. v. 3, p. 56-60, 1952.

(Manuscript received 09 August 2011; revised 30 August 2011; accepted 05 March 2012) 